INTIQAD: JURNAL AGAMA DAN PENDIDIKAN ISLAM

ISSN 1979-9950 (print) || ISSN 2598-0033 (online), http://jurnal.umsu.ac.id/index.php/intiqad DOI: 10.30596/intiqad.v12i2.5194

Vol. 12, No. 2 (December 2020)

\title{
The Factors That Affecting Students' Learning Difficulties In The Islamic Eduction Subject
}

\author{
Akrim $^{1 *}$ \\ Fakulty of Islamic Studies, University of Muhammadiyah Sumatera Utara \\ Jalan Kapten Mukhtar Basri No. 3 Medan \\ "1email: akrim@umsu.ac.id
}

\begin{abstract}
This study aims to determine the dominant factors that cause learning difficulties of students in participating in the Islamic Education (PAI) program at students of grade XI and XII at Laksamana Martadinata High School, Medan, North Sumatra. The research method used is descriptive research. This research was conducted in January to February 2020. 236 students of class XI and XII of Laksamana Martadinata Senior High School in Medan, North Sumatra were sampled in this study. Data collection techniques used in this study were by giving a questionnaire to the factors of student learning difficulties in following the Islamic Education subjects. The results showed that the internal factors causing the highest learning difficulties were health indicators with $70.68 \%$ and the external factors causing the highest learning difficulties were family indicators with $55.01 \%$.
\end{abstract}

Keyword: Learning difficulties, Islamic Education
Artikel Info

Received:

07 August 2020

Revised:

09 October 2020

Accepted:

17 November 2020

Published:

05 December 2020

Penelitian ini bertujuan untuk mengetahui faktor-faktor yang dominan yang menjadi kebiasaan belajar peserta didik dalam mengikuti program PAI pada siswa kelas XI dan XII SMA Laksamana Martadinata Kota Medan, Sumatera Utara. Metode penelitian yang digunakan adalah penelitian deskriptif. Penelitian ini dilaksanakan pada bulan Januari - Februari 2020. 212siswa kelas XI dan XII SMA Laksamana Martadinata Kota Medan, Sumatera Utara menjadi sampel dalam penelitian ini. Teknik pengumpulan data yang digunakan dalam penelitian ini yaitu dengan memberikan angket faktor-faktor kebiasaan siswa dalam mengikuti mata pelajaran PAI. Hasil penelitian menunjukkan jika kebiasaan belajar PAI yang dominan dimiliki oleh siswa kelas XI dan XII SMA 
Laksamana Martadinata Kota Medan, Sumatera Utara adalah dengan elakukan kerja kelompok dalam belajar dan yang paling sedikit dilakukan adalah belajar mandiri di rumah dengan $34,25 \%$ siswa.

\section{Kata kunci: Analisis, Kebiasaan Belajar, Pendidikan Agama Islam}

\section{A. Intrroduction}

The current curriculum in the Indonesian education system is the 2013 curriculum. The 2013 curriculum provides opportunities for students to develop abilities, talents and interests more broadly and openly in accordance with individual mastery. This is in accordance with Law on national education system number 20 of 2003 article 12 paragraph (1) point $b$, stating that students are entitled to receive educational services in accordance with their talents, interests and abilities. To realize the mandate of the Law on the National Education System, the Government issued Government Regulation on Education and Culture (Permendikbud (Indonesia terms)) number 64 of 2014 concerning Specialization in Secondary Education which is used as a reference to improve the quality of services to students so that the talents, interests and abilities of students are served so that students can determine the choice of interests in accordance with the talents and ideals for future life.

Islamic Education is one of the three subjects that must be given to students. Daulay (2014) in his book states that the contents of the curriculum of every type, path and level of education must contain one of the three compulsory subjects given to students namely Islamic education. The purpose of Islamic education itself is to create students who believe and be cautious and have noble character. To achieve this goal learning outcomes are the most important indicator in Islamic religious education.

Learning outcomes in Islamic Education subjects can be influenced by several factors, namely internal and external factors. According to Suryabrata (2011) internal factors of student learning difficulties are classified into two namely physiological factors and 
INTIQAD: JURNAL AGAMA DAN PENDIDIKAN ISLAM

ISSN 1979-9950 (print) || ISSN 2598-0033 (online), http://jurnal.umsu.ac.id/index.php/intiqad

DOI: 10.30596/intiqad.v12i2.5194

Vol. 12, No. 2 (December 2020)

psychological factors. These

External factors that influence

physiological factors can be divided into two kinds, namely the state of physical tone and certain physiological functions, especially the five senses. The state of physical tone in general can be the background of learning activities. With a fresh and not tired physical state will affect learning outcomes compared to physical conditions that are less fresh and tired. There are two things related to physical tone namely adequate nutrition and several diseases that can interfere with learning (Akrim, 2019). The physiological states of the five senses that most play a role in learning are the eyes and ears. For this reason, it is necessary to maintain the health of the patient, such as periodic doctor examinations, provision of learning tools and equipment that meet the requirements and so on. While psychological factors in learning are things that encourage student learning activities. Like the nature of curiosity and inquiry, the nature of getting sympathy from others, the nature of creative, the nature of repairing past failures with new business (A. Akrim, 2018).

student learning are factors that come from outside students. External factors are grouped into two groups, namely social factors and non-social factors. Social factors are factors that originate from humans, whether humans exist or are not directly present. The presence of other people while studying, can often interfere with learning activities. Noise when students are studying will also disrupt the learning process of students. While non-social factors are factors that are not of human origin. These factors such as the state of the air, weather, time, place or building, the tools used when studying (media).

Based on the existing problems, the researcher considers that it is necessary to conduct research related to what are the dominant factors that become learning difficulties for students in participating in the Islamic Education program, especially in class XI and XII students at Laksamana Martadinata High School, Medan, North Sumatra.

\section{B. Research Method}

The research method used is descriptive research. The purpose of this study is to describe the factors that 
ISSN 1979-9950 (print) || ISSN 2598-0033 (online), http://jurnal.umsu.ac.id/index.php/intiqad

DOI: 10.30596/intiqad.v12i2.5194

Vol. 12, No. 2 (December 2020)

cause learning difficulties in following the subject of Islamic religious education. This research was conducted in class XI and XII students of Laksamana Martadinata High School, Medan, North Sumatra. This research was conducted in January to February 2020. 236 students were sampled in this study. Data collection techniques used in this study were by giving a questionnaire to the factors of student learning difficulties in following the Islamic Education subjects. This questionnaire contains a type of closed statement to be responded by students with a total of 39 statements. The preparation of the questionnaire was adjusted to the instrument lines based on the theoretical study conducted. The following instrument lattice to compile a learning difficulties questionnaire in following the Islamic Education subjects. The questionnaire in this study was made on a Likert scale, each variable provides 4 (four) alternative answers namely Always, often, rarely/ sometimes, and Never

\section{Result And Discussion \\ Result}

Descriptive analysis is used to analyze data by describing data that has been collected from each variable studied after the research has been carried out so that it is easier to understand. The following will explain the description of the data through descriptive analysis of the learning difficulties variable of Islamic Education (PAI) that has been carried out.

\section{Internal Factors}

Internal factors that can influence student learning difficulties in Islamic Education (PAI) subjects are as follows:

\section{a. Attitude towards Learning}

In detail, reading attitudes towards learning by students is as follows.

Table 2 Attitudes towards learning

\begin{tabular}{|c|l|c|c|c|c|}
\hline $\begin{array}{l}\text { Question } \\
\text { Number }\end{array}$ & \multicolumn{1}{|c|}{ Question } & Alw. & Oft. & Som. & Nev. \\
\hline 1 & $\begin{array}{l}\text { I did not prepare a Islamic Education } \\
\text { textbook before the lesson began }\end{array}$ & $4,2 \%$ & $11,9 \%$ & $39,4 \%$ & $44,5 \%$ \\
\hline 2 & $\begin{array}{l}\text { I did not prepare other supporting } \\
\text { learning resources before the lesson } \\
\text { began }\end{array}$ & $3,8 \%$ & $9,7 \%$ & $64,9 \%$ & $21,6 \%$ \\
\hline
\end{tabular}




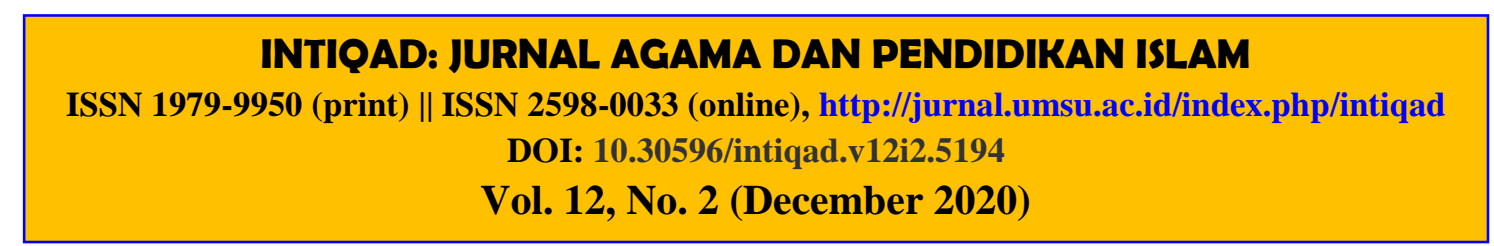

\begin{tabular}{|c|l|c|c|c|c|}
\hline 3 & $\begin{array}{l}\text { Each teacher gave a question, then I } \\
\text { answered earnestly }\end{array}$ & $12,3 \%$ & $50,4 \%$ & $35,6 \%$ & $1,7 \%$ \\
\hline 4 & $\begin{array}{l}\text { I am not trying to finish the assignment } \\
\text { from the teacher properly and correctly }\end{array}$ & $3 \%$ & $5,5 \%$ & $32,2 \%$ & $59,3 \%$ \\
\hline
\end{tabular}

Based on the table, it can be seen that the attitudes towards learning of students of class XI and XII of Laksamana Martadinata High School are 10 students (4.2\%) stating they always do not prepare Islamic Education textbooks before the lesson begins while 28 students (11.9\%) state often, 93 students (39.4\%) stated sometimes and 105 students (44.5\%) stated never. Next, 9 students $(3.8 \%)$ stated that they did not always prepare other supporting learning resources before the lesson began, while 34 students $(9.7 \%)$ stated often, 142 students $(64.9 \%)$ stated sometimes and 51 students $(21,6 \%)$ stated never. Then as many as 40 students (12.3\%) said they always answered in earnest if each teacher asked questions, while 108 students $(50.4 \%)$ stated often, 84 students students $(1.7 \%)$ stated never. A total of 7 students (3\%) stated an always did not try to complete the assignment of the teacher properly and correctly, while 13 students $(5.5 \%)$ stated often, 76 students $(32,2 \%)$ stated sometimes and 140 students (59.3\%) stated never.

Based on the data, it can be seen that the most dominant attitude towards student learning contained in my statement is not preparing other supporting learning resources before the lesson begins with $64.9 \%$ of students sometimes doing it. As for the least students do in the statement each teacher gives a question I answered earnestly with $1.7 \%$ of students never do it.

\section{b. Motivation}

In detail the learning motivation of students is as follows.

Table 3 Motivation to learn

\begin{tabular}{|c|c|c|c|c|c|}
\hline $\begin{array}{l}\text { Question } \\
\text { Number }\end{array}$ & Question & Alw. & Oft. & Som. & Nev. \\
\hline 5 & $\begin{array}{l}\text { I have never made a summary of } \\
\text { the subject matter that the teacher }\end{array}$ & $6,8 \%$ & $14,8 \%$ & $40,7 \%$ & $37,7 \%$ \\
\hline
\end{tabular}


INTIQAD: JURNAL AGAMA DAN PENDIDIKAN ISLAM

ISSN 1979-9950 (print) || ISSN 2598-0033 (online), http://jurnal.umsu.ac.id/index.php/intiqad

DOI: 10.30596/intiqad.v12i2.5194

Vol. 12, No. 2 (December 2020)

\begin{tabular}{|c|c|c|c|c|c|}
\hline & has explained & & & & \\
\hline 6 & $\begin{array}{l}\text { I ask the teacher if you have } \\
\text { difficulty during Islamic Education } \\
\text { lessons }\end{array}$ & $19.9 \%$ & $41.5 \%$ & $32.2 \%$ & $6,4 \%$ \\
\hline
\end{tabular}

Based on the table above, it can

be seen that the learning motivation of students in grade XI and XII of Laksamana Martadinata High School is 16 students $(6.8 \%)$ stating that they always never make a summary of the subject matter described by the teacher, while 35 students $(14.8 \%)$ stated frequently, 96 students $(40.7 \%)$ stated sometimes and 89 students (37.7\%) stated never. Then, as many as 47 students $(19.9 \%)$ stated that they always asked the teacher if they had difficulties during PAI lessons, while 98 students (41.5\%) stated

often, 76 students (32.2\%) stated sometimes and 15 students $(6,4 \%)$ stated never.

Based on the table above, it can be seen that the most dominant motivation for student learning in terms of motivation is in the statement I asked the teacher if having difficulties during Islamic Education lessons with $41.5 \%$ students often do it. The least amount of students did in the same statement as $6.4 \%$ of students had never done it.

\section{c. Interest to Learn}

In detail, the students' interest in learning is as follows:

Table 4 Interest to learn

\begin{tabular}{|c|l|c|c|c|c|}
\hline $\begin{array}{l}\text { Question } \\
\text { Number }\end{array}$ & \multicolumn{1}{|c|}{ Question } & Alw. & Oft. & Som. & Nev. \\
\hline 7 & $\begin{array}{l}\text { I still pay attention to the teacher } \\
\text { even though my friend jokes } \\
\text { during Islamic Education lessons }\end{array}$ & $21,2 \%$ & $54,2 \%$ & $20,8 \%$ & $3,8 \%$ \\
\hline 8 & $\begin{array}{l}\text { I pay attention to the material that } \\
\text { the teacher explains about Islamic } \\
\text { Education lessons }\end{array}$ & $39,4 \%$ & $53,4 \%$ & $5,5 \%$ & $1,7 \%$ \\
\hline 9 & $\begin{array}{l}\text { I feel disappointed if the teacher is } \\
\text { unable to attend or empty hours } \\
\text { during the Islamic Education } \\
\text { class. }\end{array}$ & $10,6 \%$ & $19,1 \%$ & $51,7 \%$ & $18,6 \%$ \\
\hline 10 & $\begin{array}{l}\text { I was not happy during the } \\
\text { Islamic Education lesson }\end{array}$ & $0,8 \%$ & $4,7 \%$ & $12,7 \%$ & $81,8 \%$ \\
\hline
\end{tabular}




\section{INTIQAD: JURNAL AGAMA DAN PENDIDIKAN ISLAM}

ISSN 1979-9950 (print) || ISSN 2598-0033 (online), http://jurnal.umsu.ac.id/index.php/intiqad

DOI: 10.30596/intiqad.v12i2.5194

Vol. 12, No. 2 (December 2020)

Based on the table above, it can be explained that the learning interest of students in class XI and XII of Laksamana Martadinata High School is as many as 50 students $(21.2 \%)$ said they always pay attention to the teacher even though my friends joked during Islamic Education lessons, while 128 students (54.2\%) stated frequently, 49 students $(20.8 \%)$ stated sometimes and 9 students (3.8\%) stated never. A total of 93 students (39.4\%) stated that they always pay attention to the material explained by teachers about Islamic Education lessons, while 126 students (53.4\%) stated often, 13 students (5.5\%) stated sometimes and 4 students (1, 7\%) stated never. Moreover, as many as 25 students $(10.6 \%)$ stated that they always felt disappointed when the teacher was unable to attend or empty hours during the Islamic Education lesson, while 45 students (19.1\%) stated often, 122 students $(51.7 \%)$ stated sometimes and 44 students (18.6\%) stated never. As many as 2 students $(0.8 \%)$ stated that they were always unhappy during Islamic Education lessons, while 11 students (4.7\%) stated often, 30 students (12.7\%) stated sometimes and 193 students $(81.8 \%)$ stated never.

Based on the table above, it can be seen that the most dominant student interest in learning is in the statement I was not happy when the Islamic Education class with $81.8 \%$ students never did it. As for the least students do on the same statement with $0.8 \%$ students always do it.

\section{d. Health}

In detail the health that can affect students is as follows:

Table 5 Health

\begin{tabular}{|c|l|c|c|c|c|}
\hline $\begin{array}{c}\text { Question } \\
\text { Number }\end{array}$ & \multicolumn{1}{|c|}{ Question } & Alw. & Oft. & Som. & Nev. \\
\hline 11 & $\begin{array}{l}\text { I try to maintain my health so that I can } \\
\text { concentrate while attending Islamic } \\
\text { Education lessons }\end{array}$ & $31,8 \%$ & $39,8 \%$ & $19,5 \%$ & $8,9 \%$ \\
\hline 12 & $\begin{array}{l}\text { My body condition is healthy when I } \\
\text { take Islamic Education lessons }\end{array}$ & $39,4 \%$ & $46,6 \%$ & $12,7 \%$ & $1,3 \%$ \\
\hline 13 & $\begin{array}{l}\text { I do not have a disorder or disability that } \\
\text { reduces my concentration when taking } \\
\text { Islamic Education lessons }\end{array}$ & $33,5 \%$ & $11,4 \%$ & $13,6 \%$ & 41,5 \\
& $\begin{array}{l}\text { I can see the media clearly displayed by } \\
\text { the teacher even though sitting in the }\end{array}$ & $34,7 \%$ & $26,7 \%$ & $30,1 \%$ & $8,5 \%$ \\
\hline
\end{tabular}


INTIQAD: JURNAL AGAMA DAN PENDIDIKAN ISLAM

ISSN 1979-9950 (print) || ISSN 2598-0033 (online), http://jurnal.umsu.ac.id/index.php/intiqad

DOI: 10.30596/intiqad.v12i2.5194

Vol. 12, No. 2 (December 2020)

\begin{tabular}{|l|l|l|l|l|l|}
\hline & back & & & & \\
\hline 15 & I listened to the teacher's voice clearly & $51,3 \%$ & $38,1 \%$ & $8,5 \%$ & $2,1 \%$ \\
\hline
\end{tabular} could always see the media clearly

Based on the above table, it can be described that the health of students of class XI and XII of Laksamana Martadinata High School is 75 students $(31.8 \%)$ who always try to maintain their health so that I can concentrate while taking PAI, while 94 students (39.8 \%) stated frequently, 46 students $(19.5 \%)$ stated sometimes and 21 students (8.9\%) stated never. A total of 93 students $(39.4 \%)$ stated that they were always healthy when taking Islamic Education lessons, while 110 students (46.6\%) stated frequently, 30 students $(12.7 \%)$ stated sometimes and 3 students $(1.3 \%)$ stated never.

As many as 79 students $(33.5 \%)$ stated that they always did not have a disability or a physical disability that reduced my concentration while attending PAI, while 27 students (11.4\%) stated frequently, 32 students (13.6\%) stated sometimes and 98 students $(41.5 \%)$ stated never. As many as 82 students (34.7\%) said they displayed by the teacher even though sitting behind, while 63 students $(26.7 \%)$ stated often, 71 students $(30.1 \%)$ stated sometimes and 20 students (8.5\%) stated never. A total of 121 students $(51.3 \%)$ said they always listened to the teacher's voice clearly, while 90 students $(38.1 \%)$ stated often, 20 students $(8.5 \%) \quad$ stated sometimes and 5 students (2.1\%) stated never.

Based on the table above, it can be seen that the most dominant internal factor in terms of health is in my statement listening to the teacher's voice clearly with $51.3 \%$ of students always doing it. The least amount of students did was stated in the statement that my body was healthy while taking the Islamic Education class with $1.3 \%$ of students never doing it.

\section{External Factors}

External factors that can affect student learning difficulties in 
INTIQAD: JURNAL AGAMA DAN PENDIDIKAN ISLAM

ISSN 1979-9950 (print) || ISSN 2598-0033 (online), http://jurnal.umsu.ac.id/index.php/intiqad

DOI: 10.30596/intiqad.v12i2.5194

Vol. 12, No. 2 (December 2020)

Islamic Education (PAI) subjects are

In detail the family factors that as follows.

can affect students are as follows:

a. Family

Table 6 Family

\begin{tabular}{|c|l|c|c|c|c|}
\hline $\begin{array}{l}\text { Question } \\
\text { Number }\end{array}$ & \multicolumn{1}{|c|}{ Question } & Alw. & Oft. & Som. & Nev. \\
\hline 16 & $\begin{array}{l}\text { My parents reminded me to } \\
\text { study }\end{array}$ & $64,4 \%$ & $22 \%$ & $10,2 \%$ & $3,4 \%$ \\
\hline 17 & $\begin{array}{l}\text { My parents paid little attention } \\
\text { to my learning achievements }\end{array}$ & $6,8 \%$ & $16,1 \%$ & $21,6 \%$ & $55,5 \%$ \\
\hline 18 & $\begin{array}{l}\text { My parents meet all my needs } \\
\text { for learning }\end{array}$ & $67,8 \%$ & $23,7 \%$ & $7,2 \%$ & $1,3 \%$ \\
\hline 19 & $\begin{array}{l}\text { Parents can afford to pay tuition } \\
\text { fees on time }\end{array}$ & $60,2 \%$ & $24,2 \%$ & $12,7 \%$ & $2,9 \%$ \\
\hline 20 & $\begin{array}{l}\text { The atmosphere at home does } \\
\text { not support me when studying } \\
\text { so I find it difficult to } \\
\text { concentrate }\end{array}$ & $5,5 \%$ & $10,2 \%$ & $25 \%$ & $59,3 \%$ \\
\hline 21 & $\begin{array}{l}\text { In the house there was never a } \\
\text { conflict/ quarrel between family } \\
\text { members, which made me disturbed } \\
\text { in learning }\end{array}$ & $18,6 \%$ & $10,6 \%$ & $28 \%$ & $42,8 \%$ \\
\hline
\end{tabular}

Based on the table above, it can be seen that the family factors experienced by students of class XI and XII of Laksamana Martadinata High School are 152 students $(64.4 \%)$ stated that they are always reminded to learn by parents, while 52 students $(22 \%)$ stated frequently, 24 students $(10.2 \%)$ stated sometimes and 8 students (3.4\%) stated never. Next, As many as 16 students (6.8\%) stated that they were not always paid attention to their learning achievement by parents, while 38

students $(16.1 \%)$ stated often, 51 students $(21.6 \%)$ stated sometimes and 131 students $(55.5 \%)$ stated never.

A total of 160 students $(67.8 \%)$ stated that they always met all their needs for learning by parents, while 56 students $(23.7 \%)$ stated often, 17 students (7.2\%) stated sometimes and 3 students (1, $3 \%)$ stated never. Then, A total of 142 students (60.2\%) stated that they were always able to pay tuition fees on time, while 57 students $(24.2 \%)$ stated frequently, 30 students $(12.7 \%) \quad$ stated 


\section{INTIQAD: JURNAL AGAMA DAN PENDIDIKAN ISLAM}

ISSN 1979-9950 (print) || ISSN 2598-0033 (online), http://jurnal.umsu.ac.id/index.php/intiqad

DOI: 10.30596/intiqad.v12i2.5194

Vol. 12, No. 2 (December 2020)

sometimes and 7 students $(2.9 \%)$

states never. Moreover, 13 students $(5.5 \%)$ stated that it was always difficult to concentrate when the atmosphere at home was not supportive while studying, while 24 students $(10.2 \%) \quad$ stated frequently, 59 students $(25 \%)$ stated sometimes and 140 students $(59,3 \%)$ stated never.

Based on the data, it can conclude that the most dominant external factor in terms of family is in the statement of parents fulfilling all my needs for learning with $67.8 \%$ of students always doing it. The least amount of students did in the same statement with $1.3 \%$ of students never doing it.

\section{b. School}

In detail the school factors that can affect students are as follows:

Table 7 School

\begin{tabular}{|c|c|c|c|c|c|}
\hline $\begin{array}{l}\text { Question } \\
\text { Number }\end{array}$ & Question & Alw. & Oft. & Som. & Nev. \\
\hline 22 & $\begin{array}{l}\text { How to teach a teacher makes me } \\
\text { bored to learn }\end{array}$ & $7,6 \%$ & $16,9 \%$ & $57,6 \%$ & $17,8 \%$ \\
\hline 23 & $\begin{array}{l}\text { The teacher's ways explain the } \\
\text { material clearly }\end{array}$ & $22 \%$ & $58,5 \%$ & $17,4 \%$ & $2,1 \%$ \\
\hline 24 & $\begin{array}{l}\text { I am lazy to go to school because I } \\
\text { get less favorable treatment from } \\
\text { my classmates }\end{array}$ & $4,2 \%$ & $4,7 \%$ & $21,6 \%$ & $69,5 \%$ \\
\hline 25 & $\begin{array}{l}\text { In the class there are no students } \\
\text { who group / distinguish friends }\end{array}$ & $11 \%$ & $19,1 \%$ & $47,9 \%$ & $22 \%$ \\
\hline 26 & $\begin{array}{l}\text { Facilities at the school support } \\
\text { teaching and learning activities }\end{array}$ & $29,7 \%$ & $41,5 \%$ & $21,6 \%$ & $7,2 \%$ \\
\hline 27 & $\begin{array}{l}\text { The training given by the teacher is } \\
\text { clear }\end{array}$ & $23,3 \%$ & $54,7 \%$ & $18,6 \%$ & $3,4 \%$ \\
\hline 28 & $\begin{array}{lcr}\text { Hot classrooms make } & \text { it } \\
\text { uncomfortable to study }\end{array}$ & $25,4 \%$ & $28 \%$ & $28,8 \%$ & $17,8 \%$ \\
\hline 29 & $\begin{array}{l}\text { I am excited to learn because the } \\
\text { classrooms are neatly organized }\end{array}$ & $19,9 \%$ & $34,3 \%$ & $42 \%$ & $3,8 \%$ \\
\hline 30 & $\begin{array}{l}\text { Classroom lighting when learning } \\
\text { to draw patterns is already good }\end{array}$ & $26,7 \%$ & $50,9 \%$ & $14,8 \%$ & $7,6 \%$ \\
\hline 31 & $\begin{array}{l}\text { The desk chairs that are used during } \\
\text { lessons are not appropriate and } \\
\text { adequate }\end{array}$ & $6,8 \%$ & $16,1 \%$ & $36,9 \%$ & $40,2 \%$ \\
\hline 32 & $\begin{array}{l}\text { During class time during the day } \\
\text { makes it difficult for me to } \\
\text { concentrate }\end{array}$ & $14 \%$ & $36 \%$ & $38,6 \%$ & $11,4 \%$ \\
\hline
\end{tabular}


INTIQAD: JURNAL AGAMA DAN PENDIDIKAN ISLAM

ISSN 1979-9950 (print) || ISSN 2598-0033 (online), http://jurnal.umsu.ac.id/index.php/intiqad

DOI: 10.30596/intiqad.v12i2.5194

Vol. 12, No. 2 (December 2020)

\begin{tabular}{|c|l|c|c|c|c|}
\hline $\begin{array}{l}\text { Question } \\
\text { Number }\end{array}$ & \multicolumn{1}{|c|}{ Question } & Alw. & Oft. & Som. & Nev. \\
\hline 33 & $\begin{array}{l}\text { Islamic Education teaching and } \\
\text { learning process is carried out in } \\
\text { accordance with the allotted time }\end{array}$ & $31,4 \%$ & $44 \%$ & $20,8 \%$ & $3,8 \%$ \\
\hline
\end{tabular}

students (11\%) stated that there

Based on the table, it can be concluded that the school factors faced by students of class XI and XII of Laksamana Martadinata High School are 18 students (7.6\%) who are always bored to learn from teaching methods, while 40 students $(16.9 \%)$ state often, 136 students (57.6\%) stated sometimes and 42 students $(17.8 \%)$ stated never. A total of 52 students $(22 \%)$ stated always explained clearly the material provided by the teacher, while 138 students $(58.5 \%)$ stated frequently, 41 students $(17.4 \%) \quad$ stated sometimes and 5 students (2.1\%) states never.

A total of 10 students $(4.2 \%)$ stated that they were always lazy to enter school because they received less favorable treatment from my classmates, while 11 students (4.7\%) stated often, 51 students $(21.6 \%)$ stated sometimes and 164 students (69.5\%) stated never. Next, as many as 26 were always no students grouping / differentiating friends in class, while 45 students (19.1\%) stated frequently, 113 students (47.9\%) stated sometimes and 52 students (22\%) stated never. Moreover, 70 students $(29.7 \%)$ stated that they were always supported by their teaching and learning activities by school facilities, while 98 students $(41.5 \%)$ stated frequently, 51 students $(21.6 \%)$ stated sometimes and 17 students $(7,2 \%)$ stated never. Last, a total of 55 students $(23.3 \%)$ stated that the training given by the teacher was always clear, while 129 students (54.7\%) stated often, 44 students $(18.6 \%)$ stated sometimes and 8 students $(3.4 \%)$ states never.

A total of 60 students $(25.4 \%)$ stated that it was always uncomfortable to study if the classrooms were hot, while 66 students (28\%) stated often, 68 students $(28.8 \%)$ stated sometimes and 42 students (17.8\%) ) states 
INTIQAD: JURNAL AGAMA DAN PENDIDIKAN ISLAM

ISSN 1979-9950 (print) || ISSN 2598-0033 (online), http://jurnal.umsu.ac.id/index.php/intiqad

DOI: 10.30596/intiqad.v12i2.5194

Vol. 12, No. 2 (December 2020)

never. Surprisingly, 47 students $(19.9 \%)$ stated that they were always enthusiastic to learn because the classrooms were neatly arranged, while 81 students $(34.3 \%)$ stated frequently, 99 students $(42 \%)$ stated sometimes and 9 students (3.8\%) states never. Then, 63 students $(26.7 \%)$ stated that the lighting of classrooms during the learning of pattern making always went well, while 120 students $(50.9 \%) \quad$ stated frequently, 35 students $(14.8 \%)$ stated sometimes and 18 students (7.6\%) stated never.

Unfortunately, 16 students $(6.8 \%)$ stated that the desk chairs used during lessons were always inadequate and inadequate, while 38 students (16.1\%) stated frequently, 87 students $(36.9 \%)$ stated sometimes and 95 students (40.2\%) stated never. 33 students (14\%) stated that lesson time during the day always made it difficult for students to concentrate, while 85 students
$(36 \%)$ stated frequently, 91 students $(38.6 \%)$ stated sometimes and 27 students (11.4\%) stated never. As many as 74 students (31.4\%) stated that the Islamic Education teaching and learning process was always carried out in accordance with the allotted time, while 104 students (44\%) stated often, 49 students (20.8\%) stated sometimes and 9 students $(3,8 \%)$ stated never.

Based on the explanation, it can be seen that the most dominant external factor in terms of school is in my statement that I am lazy to go to school because I get less favorable treatment from my classmates with $69.5 \%$ of students never doing it. The least amount of students do in the statement of the training given by the teacher clearly with $3.4 \%$ students never do it.

\section{c. Society}

In detail the community factors that can influence students are as follows. 
INTIQAD: JURNAL AGAMA DAN PENDIDIKAN ISLAM

ISSN 1979-9950 (print) || ISSN 2598-0033 (online), http://jurnal.umsu.ac.id/index.php/intiqad

DOI: 10.30596/intiqad.v12i2.5194

Vol. 12, No. 2 (December 2020)

Table 8 Society

\begin{tabular}{|c|l|l|l|l|l|}
\hline $\begin{array}{c}\text { Question } \\
\text { Number }\end{array}$ & \multicolumn{1}{|c|}{ Question } & Alw. & Oft. & Som. & Nev. \\
\hline 34 & $\begin{array}{l}\text { Youth activities in the home } \\
\text { environment reduce my study } \\
\text { time }\end{array}$ & $4 \%$ & $4 \%$ & $32 \%$ & $60 \%$ \\
\hline 35 & $\begin{array}{l}\text { I play an active role in community } \\
\text { activities that disrupt my study } \\
\text { time }\end{array}$ & $5,5 \%$ & $7,6 \%$ & $45,8 \%$ & $41,1 \%$ \\
\hline 36 & $\begin{array}{l}\text { My associate friends like playing } \\
\text { more than studying }\end{array}$ & $9,3 \%$ & $23,7 \%$ & $45,8 \%$ & $21,2 \%$ \\
\hline 37 & $\begin{array}{l}\text { Most of my friends do not to go to } \\
\text { school so I'm lazy to study }\end{array}$ & $4,2 \%$ & $3,8 \%$ & $10,2 \%$ & $81,8 \%$ \\
\hline 39 & $\begin{array}{l}\text { Television makes me concentrate } \\
\text { less on studying }\end{array}$ & $5,5 \%$ & $18,6 \%$ & $33,1 \%$ & $42,8 \%$ \\
\hline $\begin{array}{l}\text { The existence of the internet helped } \\
\text { me in studying and working on the } \\
\text { task of making patterns }\end{array}$ & $59,3 \%$ & $31,8 \%$ & $5,9 \%$ & $3 \%$ \\
\hline
\end{tabular}

$41.1 \%)$ stated never. 22 students

Based on the table above, it $(9.3 \%)$ stated that associating can be seen that the community factors faced by students of grade XI and XII of Laksamana Martadinata High School are 10 students (4\%) stating that youth activities in the home environment always reduce student learning time, while 10 students $(4 \%)$ declare often , 76 students (32\%) stated sometimes and 140 students $(60 \%)$ stated never. A total of 13 students $(5.5 \%)$ stated that they always played an active role in community activities so as to disrupt student learning time, while 18 students (7.6\%) stated frequently, 108 students $(45.8 \%)$ stated sometimes and 97 students ( students always liked to invite to play rather than study, while 56 students $(23.7 \%)$ stated often, 108 students $(45.8 \%)$ stated sometimes and 50 students $(21,2 \%)$ stated never.

A total of 10 students $(4.2 \%)$ stated that most of their peers had not gone to school so they were always lazy to learn, while 9 students $(3.8 \%)$ stated often, 24 students $(10.2 \%)$ stated sometimes and 193 students $(81.8 \%)$ stated never. A total of 13 students (5.5\%) stated television always made students concentrate less in learning, while 44 students (18.6\%) stated often, 78 students 
$(33.1 \%)$ stated sometimes and 101 students (42.8\%) stated never. A total of 140 students $(59.3 \%)$ stated that the internet always helps students in learning and doing assignments to make patterns, while 75 students $(31.8 \%)$ stated often, 14 students $(5.9 \%)$ stated sometimes and 7 students (3\%) stated never.

Based on the data, it can be described that the most dominant external factor in terms of society is found in the statement that most of my friends have not gone to school so I am lazy to learn with $81.8 \%$ of students never doing it. The least amount of students did in the statement that the internet helped me learn and work on the task of making patterns with $3 \%$ of students never doing it.

\section{Discussion}

In the discussion will be discussed in more detail the difficulty of student learning in Islamic Education subjects where there are two influencing factors namely internal factors and external factors. On internal factors, especially in terms of attitudes toward learning, it can be concluded that as many as $64.9 \%$ of the total 236 respondents sometimes do not prepare other supporting learning resources before the lesson begins, but only $1.7 \%$ of students never play around or always seriously when answering questions from the teacher do it. This is already very good because it is in accordance with the opinion of Slameto (2015) about internal factors contained in students, one of which is readiness or willingness to respond. Even though $>50 \%$ of students sometimes do not prepare supporting learning resources properly, but they are still serious in answering questions given by the teacher.

Whereas in terms of motivation it can be concluded that as many as $>50 \%$ always ask the teacher when having difficulties when studying Islamic Education subject. This has been very good because most students have been able to show that they are enthusiastic in taking Islamic Education lessons in class.

In terms of interest it can be concluded that as many as $81.8 \%$ of students always feel happy during the lessons. This is already very good because it is in accordance with the opinion of Slameto (2015) which says 
that one of the internal factors that can affect students is interest, where interest is a constant tendency to pay attention and remember some activities. Activities that are of interest to a person are given constant attention and are accompanied by pleasure. Shown by the attitude of students who always feel happy when taking the lessons, students already have considerable interest.

In terms of health, it can be concluded that as many as $51.3 \%$ of students can always listen to the teacher's voice clearly and $>50 \%$ always have a healthy body condition when taking the lessons. This is in accordance with the opinion of Sumadi Suryabrata (2011) who revealed that the internal factors of students' learning difficulties include physiological factors which include physical tone and senses. If the physiological factors of students are good, then the lessons that are followed will go well. This is indicated by the condition of the body and senses of students who are already operating quite well.

On external factors, especially family factors, it can be revealed that as many as $67.8 \%$ of students stated that their parents always meet all their needs for learning. This is already very good because $>50 \%$ of parents have paid attention to their children's education for their success in learning in accordance with Slameto (2015) about family as an external factor that can influence student learning difficulties. Whereas in terms of school factors it can be concluded that as many as $65.9 \%$ of students stated they had never been lazy to go to school because they received less favorable treatment from classmates and also the training given by the teacher was always clear.

This is already very good because it is in accordance with the opinion of Slameto (2015) which revealed that school factors including teaching methods can influence learning. Likewise with student relations with students that can provide positive and negative effects. This is indicated by students who have never been treated less favorably at school and also teachers who have given explanations about practice questions aimed at students.

In terms of community factors, it can be concluded that as many as $81.8 \%$ of students out of a total of 236 respondents said they were never lazy to learn even though most of their friends 
had not gone to school. This is already very good because it is in accordance with the opinion of Slameto (2015) which states that the community factors that can influence student learning difficulties are associates. A good friend will have a good effect on students and vice versa a bad friend will give a bad influence too. But students have shown that they are still eager to learn even though their associates don't go to school. Likewise with $>50 \%$ of students stating that they can learn and work on assignments via the internet. This has been very good because it is in accordance with community factors that can influence learning difficulties one of which is mass media where good mass media will have a good influence on students and their learning. For example, using communication tools to support learning will give students progress in their learning.

\section{E. Conclusion}

Based on the results of the analysis of the research data and the discussion described, the researcher can draw conclusions about the factors of learning difficulties in following the Islamic Education subjects of class XI and XII of
Laksamana Martadinata High School in Medan, North Sumatra, as follows:

1. Factors of learning difficulties in following the Islamic Education subjects class XI and XII of Laksamana Martadinata High School Medan in terms of internal factors of $49.69 \%$ in the always and often difficult category of learning and $50.31 \%$ in the category sometimes and not difficult. In this internal factor, the biggest factor that always and often complicates is the health factor occupies the highest percentage with $70.68 \%$ always and often becomes a factor of learning difficulties and attitudes toward learning are the lowest factors in influencing student learning with $26.38 \%$ assume always and often complicate

2. Factors of learning difficulties in following the pattern making of the students in class XI and XII of Laksamana Martadinata High School in Medan, North Sumatra, viewed from external factors of $48.78 \%$ in the always and often difficult category of learning and $51.22 \%$ in the category sometimes and does not complicate learning. The family indicator of 
ISSN 1979-9950 (print) || ISSN 2598-0033 (online), http://jurnal.umsu.ac.id/index.php/intiqad DOI: 10.30596/intiqad.v12i2.5194

Vol. 12, No. 2 (December 2020)

$55.01 \%$ is a factor that always and often complicates learning and, the school indicator is $55.22 \%$, while the community indicator is $39.09 \%$.

Based on the conclusions above, the highest internal factors causing learning difficulties are health indicators with $70.68 \%$ and the external factors causing the highest learning difficulties are family indicators with $55.01 \%$.

\section{F. Bibliography}

Arikunto, Suharsimi. (2006). Prosedur Penelitian Suatu Pendekatan Praktik. Jakarta: PT Asdi Mahasatya.

Akrim, (2019). An Integrative Islamic Education Learning System in Khairul Imam Junior High School, Medan. 10.2991/iccd-19. 2019. 15.

Akrim, A. (2018). Ilmu Pendidikan Dalam Perspektif Islam. Kumpulan Buku Dosen, 1 (1).

Annisa, N., Akrim, A., \& Manurung, A. A. (2020). Development Of Teacher's Professional Competency In Realizing Quality Of Human Resources In The Basic School. IJEMS: Indonesian Journal of Education and Mathematical Science, 1(2).
Airlangga, E., \& Akrim, A. Learning from COVID-19, Will this Pandemic Reappear: A Reflection for Indonesian Children Future.

Black, James A. dan Dean J. Champion (2009). diterjamahkan oleh E.koswara, Dira salam, dan Alfin Ruzhendi. Methods and issues in social research (metode dan masalah penelitian social). Bandung: PT. Refika Aditama.

Caryono, Suhas dan Suhartono, "Analisis Deskriptif Faktor Penyebab Kesulitan Belajar Mata Pelajaran Matematika Di SMAN 8 Purworejo Tahun Pelajaran 2012/2013, Jurnal prosiding.

Chesaria, Rusmi Dyah. (2015). "Analisis Faktor-Faktor Penyebab Kesulitan Belajar Akuntansi Perusahaan Jasa Siswa Kelas X Akuntasi SMKN 1 Surakarta Tahun Ajaran 2014/2015”, 1 (1).

Ciltas, Alper and Enver Tatar. (2011). Diagnosis Learning Difficulties Related to the Equation and Inequality that Contain Terms with Absolute Value, 1 (1).

Daryanto. (2010). Belajar Dan Mengajar. Bandung: Yrama Widya.

Dimayanti dan Mudjiono. (2013). Belajar Dan Pembelajaran. Jakarta: Rineka Cipta 


\section{INTIQAD: JURNAL AGAMA DAN PENDIDIKAN ISLAM}

ISSN 1979-9950 (print) || ISSN 2598-0033 (online), http://jurnal.umsu.ac.id/index.php/intiqad DOI: 10.30596/intiqad.v12i2.5194

Vol. 12, No. 2 (December 2020)

Dhian,

K Anggraeni. (2016). "Identifikasi Kesulitan Belajar Siswa Kelas V SDN Sosrowijayan Kota Yogyakarta", $3(5)$.

Djaali. (2013). Psikologi Pendidikan. Jakarta: Bumi Aksara

Djafar, Fatimah.” (2014). Pengaruh Kondisi Sosial Ekonomi Orang tua Terhadap Motivasi belajar Anak", 2 (1).

Djam'an, dan Muhammad Aan Komariah (2011). Metode Penelitian Kualitatif. Bandung: PT. Alfabeta.

Ghufron, Nur dan Riri Rismawati. (2014). Gaya belajar. Yogyakarta: Pustaka Pelajar.

Gunawan, Imam. (2015). Metode Penelitian Kualitatif: Teori dan Praktik. Jakarta: Bumi Aksara.

Hamalik, Oemar. (2014). Proses Belajar Mengajar. Jakarta: Bumi Aksara.

Hasbullah. (2013). Dasar-Dasar Ilmu Pendidikan. Jakarta: Rajawali Press.

Istiyanto.http://istiyanto.com/12-tipssukses-belajar-matematika/ diakases tgl 24 juni 2017 jam 11:03

Prasetia, I., Akrim, A., \& Sulasmi, E. (2020). Effective Competency Based School Model. Jurnal Tarbiyah, 27(1).
Jamal, Fakhrul. (2014). "Analisis Kesulitan Belajar Siswa Dalam Mata Pelajaran Matematika pada Materi Peluang Kelas XI IPA SMA Muhammadiyah Meulabh Johan Pahlawan". Jurnal Maju (Jurnal pendidikan Matematika), l(1).

Jamaris, Martins. (2014). Kesulitan Belajar: Prespektif, Asesmen, dan Penanggulangannya Bagi Anak Usia Dini dan Usia Sekolah. Bogor: Ghalia Indonesia.

Kusyairy, Umy. (2014). Psikologi Belajar Panduan Praktis Untuk Memahami Psikologi dalam Pemelajaran. Makassar: Alauddin University Press.

Ladiku, Meilan. Studi Tentang FaktorFaktor Penyebab Rendahnya Prestasi Belajar Siswa Kelas XI IPS Kabupaten Bone Bolango. (Skripsi: Fakultas pendidikan Universitas Negeri Gorontalo, Goronalo, 2009).

Lestari, Kurnia Eka dan Muhammad Ridwan Yudhanegara. (2015). Penilitian Pendidikan Matematika. Bandung: PT Refika Aditama.

Muijs, Daniel and David Reynolds (2008). diterjamahkan oleh Helly Prajitno Soetjipto dan Sri Mulyanti Soetjipto. Effective Teaching Evidence and Practice (Effective Teaching Teori dan 


\section{INTIQAD: JURNAL AGAMA DAN PENDIDIKAN ISLAM}

ISSN 1979-9950 (print) || ISSN 2598-0033 (online), http://jurnal.umsu.ac.id/index.php/intiqad DOI: 10.30596/intiqad.v12i2.5194

Vol. 12, No. 2 (December 2020)

Aplikasi). Yogyakarta: Pustaka Pelajar.

Mulyadi. (2008). Diagnosis Kesulitan Belajar \& Bimbingan Terhadap Kesulitan Belajar Khusus. Yogyakarta: Nuha Liter.

Mustamin, Sitti Hasmiah. (2013). Psikologi Pembelajaran Matematika. Makassar: Alauddin University Press.

Nurhayati, Etyk (2002).'Hubungan Intelegensi dan Sikap Terhadap Pelajaran Matematika Siswa Kelas I MAN Yogyakarta" (Skripsi: Fakultas Ilmu Tarbiyah Institut Agama Islam Negeri Sunan Kalijaga Yogyakarta. Yogyakarta.

Padmavity, (2015). "Mathematics Disability-Unperceptive Truth", 1 (5).

Rahayu, Mardiyatun Mugi. (2015). "Pengaruh Kebiasaan belajar Terhadap Hasil Belajar Matematika Siswa Kelas V SD Negeri Daerah Binaan II Kecamatan Ajibarang Banyumas" (Skripsi; Fakultas Ilmu Pendidikan Univesrsitas Negeri Semarang. Semarang.

Sangadji, Etta Mamang dan Sopiah. (2010). Metodologi Penelitian: pendekatan praktis dalam penilitian. Yogyakarta: Penerbit Andi.
Sardiman. (2003). Interaksi Dan Motivasi Belajar Mengajar. Jakarta: PT Raja Grafindo Persada.

Slametto. (2010). Belajar Dan Faktor Yang Mempengaruhinya. Jakarta: Rineka Cipta.

Sudjono, Anas. (2015). Pengantar Evaluasi Pendidikan. Jakarta: Rajawali Pres.

Sugiyanto. Psikologi Pendidikan Diagnostik Belajar. Yogyakarta: UNY.

Sugiyono. (2008). Metode Penilitian Pendidikan: pendekatan kuantitatif, kualitatif dan $R \& D$. Bandung: Alfabeta.

Sumadi Suryabrata. (2014). Metodologi Penilitian. Jakarta: Rajawali Pres,

Suryanih. (2011).'Diagnosis kesulitan belajar matematika siswa dan solusinya dengan pembelajaran remedial". (Skripsi) Fakultas Tarbiiyah Jakarta: .UIN Syarif Hidayatullah.

Sunarti, (2013). "Pengaruh Intelegensi dan Motivasi Belajar Terhadap Prestasi Belajar Siswa Kelas X SMAN Purworejo", 2 (4).

Susanti, Anis, (2015). "Pengaruh Motivasi Belajar Siswa terhadap Prestasi Belajar Matematika Siswa", Vol.3, No.2.

Tim Syaamil Al-Qur'an. (1435H). AlQur'anul Karim Terjemah Tafsir 
INTIQAD: JURNAL AGAMA DAN PENDIDIKAN ISLAM

ISSN 1979-9950 (print) || ISSN 2598-0033 (online), http://jurnal.umsu.ac.id/index.php/intiqad DOI: 10.30596/intiqad.v12i2.5194

Vol. 12, No. 2 (December 2020)

Per kata (Edisi tahun 2007)

Bandung: Syaamil Al-Qur'an.

Wahyuningsih, Istiqomah Risa "Hubungan Kebiasaan Belajar dengan Prestasi Belajar Mahasiswa Regular Semester IV Kebidanan UNS" Karya Tulis Ilmiah: Kebidanan UNS (2009).

Widyasari, Ni Made Dwi, I Gede Meter, I Gusti Oka Negara. (2015). Analisis Kesulitan-Kesulitan
Belajar Matematika Siswa Kelas IV dalam Implementasi Kurikulum 2013 di SD Piloting Se-Kabupaten Gianyar, 3 (1). 